\title{
Christophe Rouil, Formose, des batailles presque
} oubliées...

Taipei, Les éditions du Pigeonnier, 2001, 191 p.

\section{Ann Heylen}

\section{OpenEdition}

\section{Journals}

Édition électronique

URL : http://journals.openedition.org/chinaperspectives/814

DOI : $10.4000 /$ chinaperspectives.814

ISSN : 1996-4617

\section{Éditeur}

Centre d'étude français sur la Chine contemporaine

Édition imprimée

Date de publication : 1 mars 2004

ISSN : 2070-3449

\section{Référence électronique}

Ann Heylen, « Christophe Rouil, Formose, des batailles presque oubliées... », China Perspectives [En ligne], 52 I march-april 2004, mis en ligne le 24 avril 2007, consulté le 22 septembre 2020. URL : http:// journals.openedition.org/chinaperspectives/814 ; DOI : https://doi.org/10.4000/chinaperspectives. 814

Ce document a été généré automatiquement le 22 septembre 2020.

(c) All rights reserved 


\section{Christophe Rouil, Formose, des batailles presque oubliées...}

Taipei, Les éditions du Pigeonnier, 2001, 191 p.

Ann Heylen

\section{NOTE DE L'ÉDITEUR}

Translated from the French original by Philip Liddell

1 This book fills a gap in the history of Taiwan and France in the nineteenth century. Christophe Rouil narrates an all but forgotten episode in the relations between the two countries. The accumulated material on the battles that took place at Keelung, Tamsui and the Pescadores in 1884 and 1885, during the Franco-Chinese War, opens up an interesting avenue for research. Rouil informs us about equipment, strategy and military personnel, thus contributing to the history of gunboat diplomacy at the end of the nineteenth century in Asia.

2 The passages devoted to the participation of African forces and the Foreign Legion under Admiral Courbet's command give these episodes their rightful place in the French colonial venture. The reader will enjoy the personal accounts of Captain Garnot, Admiral Courbet and Major Lange. The book also prints the Franco-Chinese Treaty of June $9^{\text {th }} 1885$.

3 In his conclusion, Rouil goes back over the legacy of France's colonial venture in Taiwan. He tells the story of the French cemetery at Keelung and the monument to Admiral Courbet at Makung in the Pescadores. In so doing, he asks questions that set us thinking: about how historical memory is built up in France and in Taiwan, and about the commemoration of those who have sacrificed their lives in international conflicts.

4 The book's illustrations deserve special mention. In addition to maps, there are numerous photos and drawings of French warships, battles, monuments and 
landscapes. This contribution deserves to be taken further, this time with the addition of Chinese sources. 